Check for updates

New York, USA

Cite this as: BMJ 2020;371:m4246 http://dx.doi.org/10.1136/bmj.m4246 Published: 02 November 2020

\title{
Covid-19: US cases soar as Fauci warns of tough times ahead
}

\section{Janice Hopkins Tanne}

Covid-19 cases hit record levels in the US just days before the 3 November election, with 99321 new cases on 30 October. President Donald Trump insisted the country was "rounding the turn" on the pandemic and held crowded rallies at which very few wore masks. ${ }^{1}$

Anthony Fauci, director of the National Institute of Allergy and Infectious Diseases, told the Washington Post that in the next few weeks the US might see 100 ooo or more cases per day and increasing deaths. ${ }^{2}$ He said, "We're in for a whole lot of hurt. It's not a good situation. All the stars are aligned in the wrong place as you go into the fall and winter season, with people congregating at home indoors. You could not possibly be positioned more poorly."

Fauci said that the Trump administration was focused on a vaccine and that the White House task force on covid-19 had been meeting less frequently. He and Deborah Birx, the task force coordinator, no longer have regular access to Trump and have turned to using media interviews and television to spread the message of masks, social distancing, and hand washing to the public. Birx has been travelling cross-country to advise state and local leaders.

Fauci also criticised Trump's new covid-19 adviser, Scott Atlas, a neuroradiologist with no experience in public health or infectious diseases. "I have real problems with that guy. He’s a smart guy who’s talking about things that he doesn't have any real insight or knowledge or experience in," Fauci said. Atlas has endorsed a policy of allowing covid-19 to spread among healthy young people and allowing the economy to keep running.

White House spokesman Judd Deere said, “It's unacceptable and breaking with all norms for Dr Fauci, a senior member of the president's coronavirus taskforce and someone who has praised President Trump's actions throughout this pandemic, to choose three days before an election to play politics."3

As of 1 November, the US has reported 9205570 cases and 230972 deaths, by far the highest in the world, although the US has only $4.25 \%$ of the world's population. ${ }^{4}$

Cases are increasing in 42 of the 50 states, especially in the upper Midwest states of North Dakota, South Dakota, Wisconsin, Montana, and Iowa.

On 30 October at a rally in Michigan, Trump claimed that doctors were inflating the number of deaths from covid-19 because that meant they were paid more. He gave no evidence for his claim. ${ }^{5}$

Susan Bailey, president of the American Medical Association, immediately rejected Trump's claim. She said, "Throughout this pandemic, physicians, nurses, and frontline healthcare workers have risked their health, their safety, and their lives to treat patients and defeat a deadly virus. They did it because duty called and because of the sacred oath they took. The suggestion that doctors-in a public health crisis-are overcounting covid-19 patients or lying to line their pockets is a malicious, outrageous, and completely misguided charge. Covid-19 cases are at record highs today. Rather than attacking us and lobbing baseless charges at physicians, our leaders should be following the science and urging adherence to the public health steps we know work-wearing a mask, washing hands, and practising physical distancing."6

Wisconsin governor Tony Evers, a Democrat in a state where cases are rising rapidly, said, "We're in a very difficult situation here. We should be pulling together."

Covid-19: US breaks daily record with over 99000 new cases as surge quickens. New York Times. 31 October 2020. www.nytimes.com/live/2020/10/30/world/covid-19-coronavirus-updates.

2 Dawsey J, Abutaleb Y. "A whole lot of hurt": Fauci warns of covid-19 surge, offers blunt assessment of Trump's response. Washington Post. 31 October 2020. www.washingtonpost.com/politics/fauci-covid-winter-forecast/2020/10/31/e3970eb0-1b8b-11eb-bb35-2dcfdab0a345_story.html.

3 Mena K. White House rips Fauci after criticism of Atlas and Trump's pandemic response. CNN.com. 1 November 2020. www.cnn.com/2020/10/31/politics/white-house-fauci-trump-atlas-pandemic-response/index.html.

4 Covid-19 dashboard by the Center for Systems Science and Engineering at Johns Hopkins University. https://gisanddata.maps.arcgis.com/apps/opsdashboard/index.html\#/bda7594740fd40299423467b48e9ecf6.

$5 \quad$ Hunnicutt T, Alper A. Trump derides doctors as covid surges, Biden says Trump is "giving up" on virus. Reuters. 30 October 2020. www.reuters.com/article/usa-election/trump-derides-doctors-as-covidsurges-biden-says-trump-giving-up-on-virus-idUSKBN27G024.

6 AMA statement on ongoing attacks on physicians treating COVID patients. American Medical Association press statement. 30 October 2020. www.ama-assn.org/press-center/ama-statements/ama-statement-ongoingattacks-physicians-treating-covid-patients.

7 Coleman J. Wisconsin governor on Trump's claim doctors aiming to make money: "It is such a stupid thing to say." The Hill.com. 1 November 2020. https://thehill.com/homenews/sunday-talk-shows/523837-wisconsingovernor-on-trumps-claim-doctors-aiming-to-make-money. 